\title{
Analisa Tutupan Kanopi Mangrove Dengan Metode Hemispherical Photography di Desa Betahwalang, Kabupaten Demak
}

\author{
Muksin Purnama*, Rudhi Pribadi, Nirwani Soenardjo \\ Departemen IImu Kelautan, Fakultas Perikanan dan IImu Kelautan, Universitas Diponegoro \\ JI. Prof.H.Soedarto S.H, Tembalang,Semarang, Jawa Tengah 50275 Indonesia \\ ${ }^{*}$ Corresponding author, e-mail : Muksinpurnama1998@gmail.com
}

\begin{abstract}
ABSTRAK: Ekosistem mangrove merupakan ekosistem yang tumbuh di daerah bersalinitas cukup tinggi yang memiliki kemampuan adaptasi di daerah intertidal.Hutan Mangrove di Desa Betahwalang, Kecamatan Bonang, Kabupaten Demak tumbuh di sepanjang muara sungai desa hingga pesisir pantai.Keberadaan hutan mangrove adalah sebagai sumber nutrien bagi rajungan di Betahwalang. Sumber nutrien mangrove didapatkan salah satunya dari serasah mangrove. Banyak sedikitnya serasah mangrove dipengaruhi oleh kerapatan dan tutupan kanopi mangrove. Tujuan dari penelitian adalah untuk menganalisis persentase tutupan kanopi mangrove di Desa Betahwalang. Metode deskriptif adalah metode yang dipilih dalam penelitian ini. Stasiun lokasi penelitian ditentukan menggunakan purposive sampling. Untuk mengetahui tutupan kanopi mangrove digunakan metode Hemispherical Photography. Metode Hemispherical Photographyadalah metode dengan menghitung luasan tutupan kanopi dengan menggunakan kamera dari bawah kanopi pohon. Metode ini menghasilkan data yang lebih akurat dikarenakan luas wilayah yang ditangkap dengan kamera lebih spesifik sehingga menggambarkan tutupan kanopi pohon sesungguhnya. Pengambilan data tutupan kanopi mangrove menggunakan metode Hemispherical Photography menggunakan kamera depan handphone OPPO F1 dengan resolusi kamera 8 megapixel dengan resolusi HD (1.280 x 720)pada suatu titik pengambilan foto. Teknik ini digunakan dalam plot $10 \mathrm{~m} \times 10 \mathrm{~m}$ dan dianalisis menggunakan software Ms. excel 2013 dan Image J. Penelitian ini dilakukan pada bulan Maret - April 2019 dengan total stasiun berjumlah 4 stasiun. Hasil penelitian ini ditemukan 12 spesies mangrove, 5 diantaranya terdapat di dalam plot pengambilan data. Spesies mangrove yang ditemukan di dalam plot yaituRhizophora mucronata, Rhizophora apiculata, Avicennia alba, Avicennia marina dan Sonneratia caseolaris. Nilai kerapatan yang didapatkan berkisar 1.066 - 3.066 ind/hadan nilai tutupan kanopi mangrove sebesar 81,07\% yang tergolong kedalam kategori padat.
\end{abstract}

Kata Kunci: Betahwalang; Mangrove; Tutupan Kanopi

\section{Mangrove Canopy Cover Analysis Using Hemispherical Photography Method in Betahwalang,Demak}

ABSTRACT: Mangrove ecosystems is that ecosystems grow in areas of high enough salinity that have the ability to adapt in intertidal zone. Mangrove forest in the Betahwalang village, Demak Regency grows along riverbank from village are to the river mount. The existence of mangrove forest is a source nutrient for crabs in Betahwalang. Mangrove nutrient obainted form litter mangrove. Litter mangrove was affected by the density and canopy cover mangrove. The purposes of this research is to analyzedmangrove canopy cover in Betahwalang, Demak. Descriptive method is the method chosen in this study. Sampling station was designated used purposive sampling methodand mangrove canopy cover was determined using hemispherical photography method. The method was basically calculatingthe extent of canopy cover by using camera positionedunder a trees canopy. This method believed to be relatively accurate on determining the actual cover area since the area captured by camera are precisely specificbecause of an area captured by the camera more specific sodescribe the actual tree canopy cover. This research was conducted in March - April 2019 Using 4 sampling station, each with three replication of sampling plot. Retrieval of canopy cover data used hemispherical photography method used the mobile phone front camera with 8 megapixel camera resolution with $H D$ resolution (1.280 $\times 720)$ at a point of taked photos. This method used in $10 \mathrm{~m} \times 10 \mathrm{~m}$ plot and 
analyzed used software Ms.excel 2013 and Image J.The research found12 mangrove species, 5 in the plot. Mangrove species in the plot mean Rhizophora mucronata, Rhizophora apiculata, Avicennia alba, Avicennia marina dan Sonneratia caseolaris. Density have ranged 1.066- 3.066 ind/ha and canopy covercover of trees canopy and so classified as dense canopy cover of $81.07 \%$ were classified into solid categories.

Keywords: Betahwalang, Mangrove, Canopy Cover

\section{PENDAHULUAN}

Hutan mangrove merupakan hutan yang tumbuh di daerah pasang surut dengan karakterisktik tanah berlumpur atau berpasir serta memiliki kemampuan adaptasi sangat baik ketika daerah pasang surut mengalami surut terendah sampai pasang tertinggi (Fuady et al.,, 2013). Hutan mangrove didalam eksositem perairan memiliki peranan yang tidak dapat digantikan peranananya karena fungsi dan keberadanya. Menurut Susilo (2017) hutan mangrove Hutan mangrove memiliki fungsi baik secara fisik, ekologis, dan ekonomi.

Kanopi atau sering disebut juga dengan istilah tajuk pohon adalah suatu kondisi yang terbentuk oleh cabang - cabang dan daun pohon saling tumpang tindih. Peran kanopi mangrove dapat mempengaruhi proses fotosintesis adalah dari bentuk dan kerapatan tajuk, semakin rapat tajuk maka akan semakin sulit cahaya matahari menembus kanopi pohon sehingga mangrove dengan kategori anakandan semai kurang dalam mendapatkan kebutuhan sinar matahari (Sadono, 2018). Untuk mengetahui lebar tajuk dalam suatu ekosistem salah satunya adalah dengan menggunakan metode hemispherical photography (Pretzsch et al. 2015).

Hemispherical photography merupakan suatu metode fotografi yang digunakan untuk melihat tutupan kanopi mangrove atau tutupan kanopi hutan darat melalui foto dengan kamera. Dalam hal ini yang digunakan adalah kamera depan Handphone (HP) dikarenakan memiliki keunggulan secara in heren dengan waktu, tutupan awan dan tahun. Metode hemispherical photography menggunaka kamera HP adalah metode tidak langsung untuk mengukur transmisi cahaya. Metode fotografi lainya untuk menghitung tutupan kanopi pohon adalah menggunakan metode fotografi tertutup tidak menggunakan lensa mata ikan dan lebih fokus pada analisis parameter kanopi seperti indeks luasan daun (Bianchi et al., 2017). Metode hemispherical photography ini cukup baru digunakan di Indonesia pada ekosistem mangrove karena di Indonesia dalam menentukan tutupan kanopi biasanya menggunakan metode dengan batuan citra satelit akan tetapi metode ini banyak kekurangan seperti hasil didapatkan kurang akurat karena dalam perhitungan mencakup wilayah yang luas. Metode hemispherical photography perlu dikembangkan di Indonesia karena penerapannya mudah dengan biaya lebih murah dan hasil lebih akurat dibanding dengan metode citra satelit untuk mengetahui suatu kondisi ekosistem mangrove di suatu daerah selain menghitung nilai kanopi pohon juga diperlukan menghitung nilai dari struktur dan komposisinya (Baksir et al., 2018).

Desa Betahwalang merupakan salah satu desa pesisir di Kabupaten Demak, Jawa Tengah. Masyarakat Betahwalang memiliki profesi mayoritas sebagai nelayan rajungan sehingga Desa Betahwalang terkenal sebagai desa pengekspor rajungan di Indonesia dan Dunia (Edi et al., 2018). Keberadaan rajungan di perairan pantai utara Desa Betahwalang tidak dapat dilepaskan dengan keberadaan hutan mangrove di sepanjang muara sungai desa hingga pesisir pantai. Keberadaan hutan mangrove adalah sebagai sumber nutrien bagi rajungan di Betahwalang. Sumber nutrien mangrove didapatkan salah satunya dari serasah mangrove. Banyak sedikitnya serasah mangrove dipengaruhi oleh kerapatan dan tutupan tajuk mangrove. Tujuan penelitian adalah mengetahui nilai persentase tutupan kanopi mangrove dengan metode Hemispherical Photography.

\section{MATERI DAN METODE}

Materi yang digunakan dalam penelitian ini adalah vegetasi mangrove. Metode yang dipilih adalah metode survei. Metode survei termasuk kedalam metode deskriptif. Menurut Nasir (1998) 
dalam Mauludin et al. (2018), Metode survei adalah metode pengumpulan data dengan mengambil sebagian data dari wilayah sehingga diharapkan sudah mewakili kondisi lingkungan dari objek yang diteliti oleh peneliti. Data dideskripsikan untuk mendapatkan data secara sistematis, faktual, dan akurat dengan fenomena yang diteliti.

Metode penentuan lokasi penelitian ditentukan dengan metode purposive sampling. Metode ini dipilih karena memiliki kelebihan seperti waktu, tenaga, dan biaya yang dikeluarkan lebih minimum dengan cangkupan wilayah yang telah mewakili kondisi tutupan kanopi mangrove di Desa Betahwalang. Penentuan titik stasiun penelitian dilakukan dengan pengamatan secara langsung dilapangan ketika survei pendahuluan (ground check). Berdasarkan hasil survei pendahuluan stasiun penelitian ditentukan berdasarkan dominansi spesies tertentu yang dapat mewakili ekosistem mangrove di Desa Betahwalang (Gambar 1) dengan jumlah total 4 Stasiun lokasi penelitian dengan nama Stasiun Betahwalang (BW). Stasiun BW 1 didominansi oleh genus Rhizophora, Stasiun BW 2 dan BW 3 didominansi oleh genus Rhizophora dan Avicennia, sedangkan Stasiun BW 4 didominansi oleh genus Avicennia. Jarak antar stasiun adalah lebih dari $300 \mathrm{~m}$ dan setiap stasiun dilakukan penggelaran plot sebanyak 3 kali.

Tutupan kanopi mangrove diukur menggunakan metode Hemispherical Photography menggunakan kamera depan Handphone OPPO F1 dengan resolusi kamera 8 megapixel pada suatu titik pengambilan foto. Metode ini tergolong baru di Indonesia untuk menghitung tutupan kanopi mangrove. Ilustrasi metode ini dapat dilihat pada Gambar 2. Menurut Dharmawan dan Pramudji (2017) metode ini digunakan didalam plot 10x10 m.
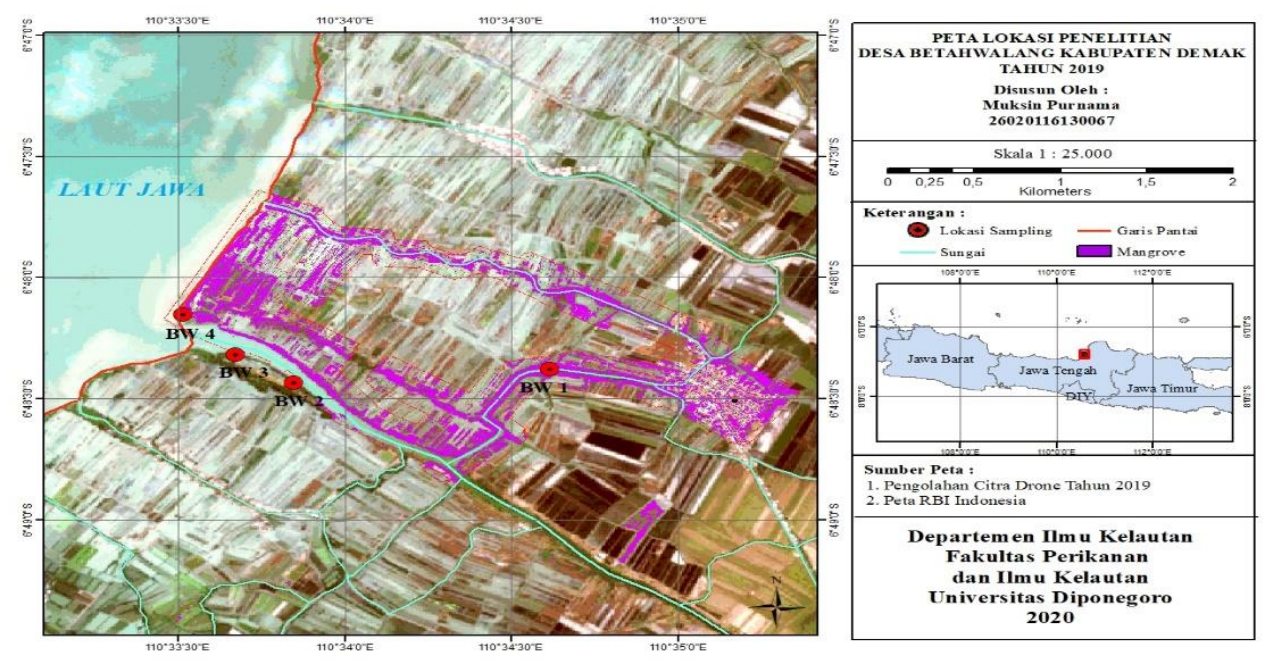

Gambar 1. Peta Lokasi Penelitian di Desa Betahwalang, Kecamatan Bonang, Kabupaten Demak.

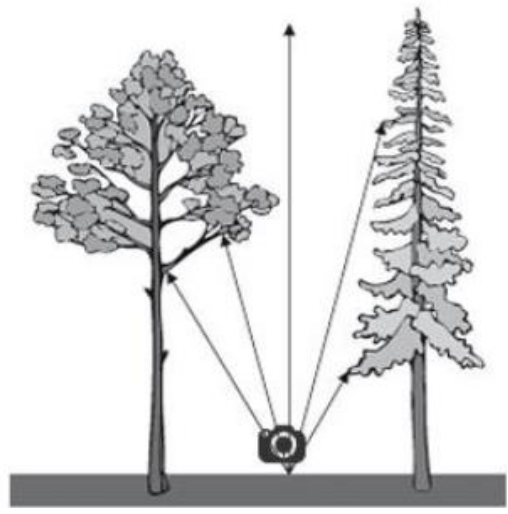

Gambar 2. Ilustrasi Metode Hemispherical Photography untuk Mengukur Tutupan Kanopi Mangrove (Dharmawan dan Pramudji, 2017). 
Pengambilan data dilakukan menggunakan kamera handphone bagian depan yang diarahkan tegak lurus kearah langit. Jumlah pengambilan foto ditentukan berdasarkan kondisi hutan mangrovenya (Gambar 3). Titik pengambilan foto harus berada diantara pohon. Hal yang perlu hidari adalah pemotretan disamping batang pohon, pengambilan foto berganda, dan hidarkan foto dari sorotan sinar matahari.

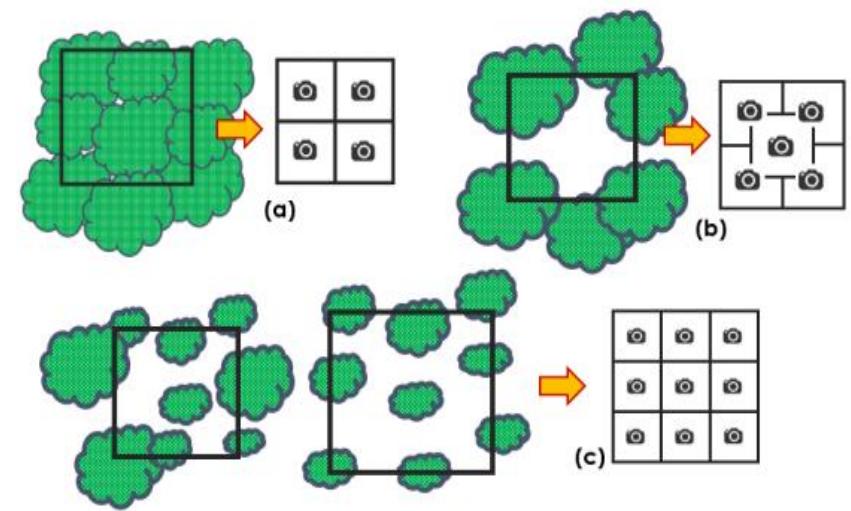

Gambar 3. Titik dan Jumlah Pengambilan Foto Berdasarkan Kondisi Hutan Mangrove (Dharmawan dan Pramudji, 2017).

Konsep dari analisis ini adalah pemisahan warna pixel langit (Warna putih) dan warna pixel vegetasi mangrove (warna hitam). Menurut Menteri Lingkungan Hidup No. 201 tahun 2004 nilai dari tutupan kanopi mangrove dikategorikan menjadi 3 yaitu; jarang $(<50 \%)$, sedang (50 $<75 \%$ ), dan padat ( $\geq 75 \%$ ). Analisis tutupan kanopi dilakukan dengan menghitung persentase jumlah pixel tutupan vegetasi mangrove dalam analisis gambar binner (Chianucci and Andrea, 2012) dengan rumus:

$$
\begin{aligned}
& \text { \% tutupan (cover) mangrove }=\frac{P 255}{\Sigma P} \times 100 \% \\
& \text { Dimana: } \mathrm{P} 255=\begin{array}{l}
\text { Jumlah Pixel yang bernilai } 255 \text { sebagai } \\
\text { interpretasi tutupan kanopi mangrove }
\end{array} \\
& \Sigma \mathrm{P}=\text { Jumlah seluruh pixel }
\end{aligned}
$$

Berdasarkan Keputusan Menteri Lingkungan Hidup No. 201 tahun 2004 kriteria tutupan kanopi mangrove terbagi menjadi beberapa kelompok yang ditunjukan pada Tabel 1. Pertumbuhan ketinggian pohon mangrove akan menyebabkan terjadinya perubahan ukuran dan bentuk pohon mangrove yang pada giliranya akan menentukan bentuk morfologi dari mangrove sendiri yang berpengaruh kedalam pengukuran ketinggian pohon Pengukuran tinggi pohon menggunakan metode teorema pythagoras dengan cara menggunakan rol meter atau menggunakan plot $10 \mathrm{~m} \mathrm{x}$ $10 \mathrm{~m}$ kemudian bagian ujung paling atas pohon di ukur sudutnya menggunakan aplikasi protactor kemudian dicatat pada lembar kerja. Aplikasi protactor dapat didowload melalui playstore, kemudian hasil perhitungan dimasukan kedalam tabel perhitungan tinggi pohon pada microsoft excel (Marhamah, 2015).

Tabel 1. Standar Baku Kerusakan Hutan Mangrove Berdasarkan Keputusan Menteri Lingkungan Hidup No.201 tahun 2004

\begin{tabular}{cccc}
\hline Kriteria & & Penutupan (\%) & Kerapatan \\
\hline Baik & Padat & $\geq 75 \%$ & $\geq 1500$ \\
& Sedang & $50-75 \%$ & $1000-1500$ \\
Rusak & Jarang & $<50 \%$ & $<1000$ \\
\hline
\end{tabular}

\section{HASIL DAN PEMBAHASAN}

Hasil penelitian menunjukan ditemukan Lima (5) spesies mangrove berada dalam plot yaitu, Rhizophora mucronata, Rhizophora apiculata, Avicennia alba, Avicennia marina dan Sonneratia caseolaris dapat dilihat pada persebaran spesies Gambar 4. Nilai Kerapatan total pada kategori 
pohon tertinggi didapatkan di Stasiun BW 1 sebesar 3.066 ind/ha kemudian diikuti Stasiun BW 2, BW 3 dan BW 4 sebesar 3.033 ind/ha, 1.967 ind/ha, 1.066 ind/ha secara berurutan. Nilai Kerapatan Stasiun BW 1 dan BW 2 tidak jauh berbeda (Gambar 5).

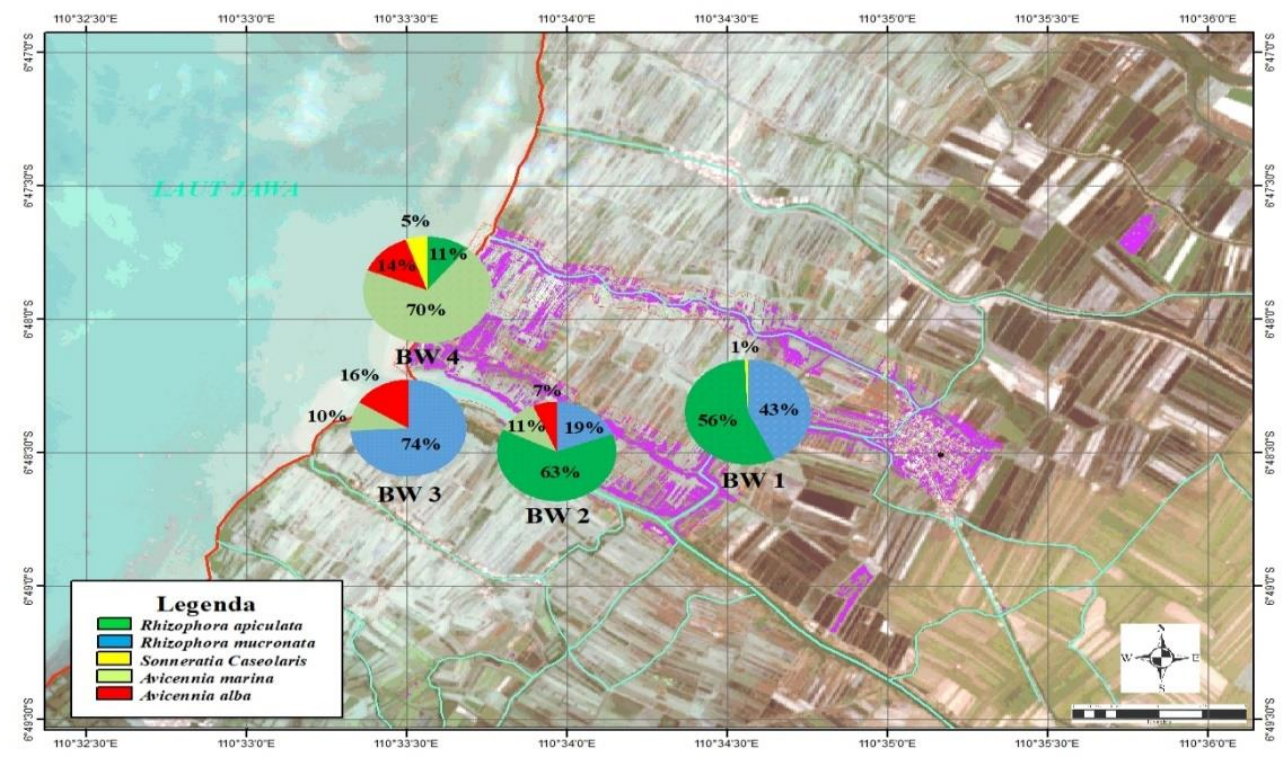

Gambar 4. Peta Distribusi Spesies mangrove di Seluruh Stasiun Penelitian

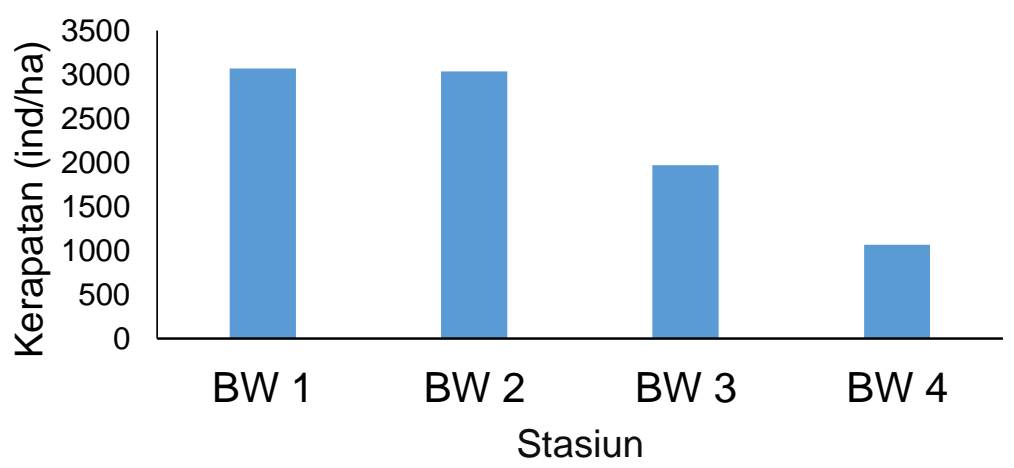

Gambar 5. Distribusi Nilai Kerapatan Total (K) Mangrove di Setiap Stasiun Pada Kategori Pohon.

Lima spesies mangrove di dalam plot transek didominansi oleh spesies Rhizophora mucronata, Rhizophopra apiculata dan Avicennia marina hal ini dikarenakan spesies tersebut sudah termasuk umum banyak di jumpai di seluruh pantai utara jawa. Menurut Tomlinson (1994), bahwa Rhizophora sp. dan Avicennia sp. membentang sepanjang wilayah Asia Tengggara hingga Queensland, Australia dan Papua New Guinea di sebelah selatan dan Filipina di sebelah utara. Spesies yang ditemukan lebih sedikit dibandingkan di kawasan Ujung Piring, Kabupaten Jepara (Mauludin et al., 2018) yang menemukan total 23 spesies mangrove dengan 7 spesies ada di dalam plot transek dan 16 spesies di luar transek. Hal ini diduga lokasi di Ujung Piring, Kabupaten Jepara lebih baik untuk pertumbuhan mangrove karena merupakan kawasan fringing mangrove forest atau sempadan pantai, vegetasi dikawasan ini relatif tertutup dari pengaruh energi gelombang dari laut. Spesies Rhizophora mucronata, Rhizophopra apiculata, dan Avicennia marina ditemukan di 3 Stasiun dari 4 Stasiun yang ada. Stasiun BW 1, 2 didominansi spesies Rhizophora apiculata, Stasiun BW 3 didominansi oleh spesies Rhizophopra mucronata sedangkan Stasiun BW 4 didominansi spesies Avicennia marina.

Perbedaan kondisi lingkungan diduga sangat berpengaruh terhadap spesies mangrove yang tumbuh. Lokasi yang selalu tergenang air banyak di jumpai spesies Rhizophora mucronata dan Rhizophora apiculata sedangkan lokasi tidak terendam oleh air banyak dijumpai spesies Avicennia 
marina. Akar Rhizophora sp. memiliki lentisel yang merupakan struktur penyerap oksigen terlarut dari air, tanah, atau udara secara difusi sebagai bentuk adaptasi terhadap lingkungan yang miskin oksigen sehingga Rhizophora sp. mampu beradaptasi dengan lingkungan selalu terendam air. Hasil penelitian sama dengan penelitian oleh Akbar et al. (2017) di Teluk Dodinga, Kabupatan Halmahera Barat mengatakan bahwa pada penelitianya didominansi oleh mangrove dari famili Rhizophoraceae. Hal ini sesuai dengan Tomlinson (1994), bahwa mangrove dari famili Rhizophoraceae banyak tersebar di beberapa pulau di Indonesia.

Kerapatan Mangrove tertinggi didapatkan di Stasiun BW 1 sebesar 3.066 ind/ha didominansi oleh Rhizophora apiculata, hal ini dikarenakan stasiun BW 1 memiliki distribusi nilai diameter paling tinggi pada kelas $5-<10 \mathrm{~cm}$ dan jarang ditemui pada kategori diameter $>20 \mathrm{~cm}$ dibandingkan dengan Stasiun BW 3 yang memiliki kerapatan 1.967 ind/ha dikarenakan masih banyak ditemui diameter $>20 \mathrm{~cm}$. Cintron dan Novelli (1984) menjelaskan bahwa semakin besar nilai diameter batang di dalam suatu plot maka akan semakin kecil nilai Kerapatan mangrove. Selain ukuran diameter jumlah spesies di dalam plot akan mempengaruhi nilai Kerapatan. Kerapatan terendah di Stasiun BW 4 sebesar 1.066 meskipun hanya dijumpai kategori diameter pada kelas $5-<10 \mathrm{~cm}$ hal ini dikarenakan jumlah spesies yang dijumpai lebih sedikit dibandingkan stasiun lain. Hasil kerapatan lebih besar dibandingkan dengan Kerapatan mangrove di di kawasan Kemujan Karimunjawa (Kurniawan, Pribadi \& Nirwani, 2014) sebesar 2.127 ind/ha didominansi oleh spesies Ceriops tagal. Perbedaan hasil ini dikarenakan perbedaan ukuran diameter di kawasan Kemujan Karimunjawa (Kurniawan, Pribadi \& Nirwani, 2014) lebih besar dibandingkan dengan lokasi penelitian.

Pengukuran tinggi pohon mangrove bertujuan untuk mengetahui distribusi pohon mangrove di lokasi penelitian. Berdasarkan hasil analisis (Gambar 6) ditribusi tinggi pohon Terbagi menjadi 4 kelas yaitu $<6 \mathrm{~m}, 6-<9 \mathrm{~m}, 9-<12 \mathrm{~m}$, dan $\geq 12 \mathrm{~m}$. Tinggi pohon semua kelas ditemukan di 3 lokasi penelitian. Lokasi tersebut meliputi Stasiun BW 1, BW 2, dan BW 3, sedangkan untuk Stasiun BW 4 hanya ditemukan 1 kelas tinggi pohon yaitu $<6 \mathrm{~m}$. Tinggi pohon ditemukan di setiap stasiun didominansi oleh setiap kelas yang berbeda - beda. Stasiun BW 1 didominansi oleh kelas ketinggian 12 m, Stasiun BW 2 didominansi oleh kelas ketinggian 6-<9 m, kemudian untuk Stasiun BW 3 didominansi oleh kelas ketinggian $9-<12 m$.
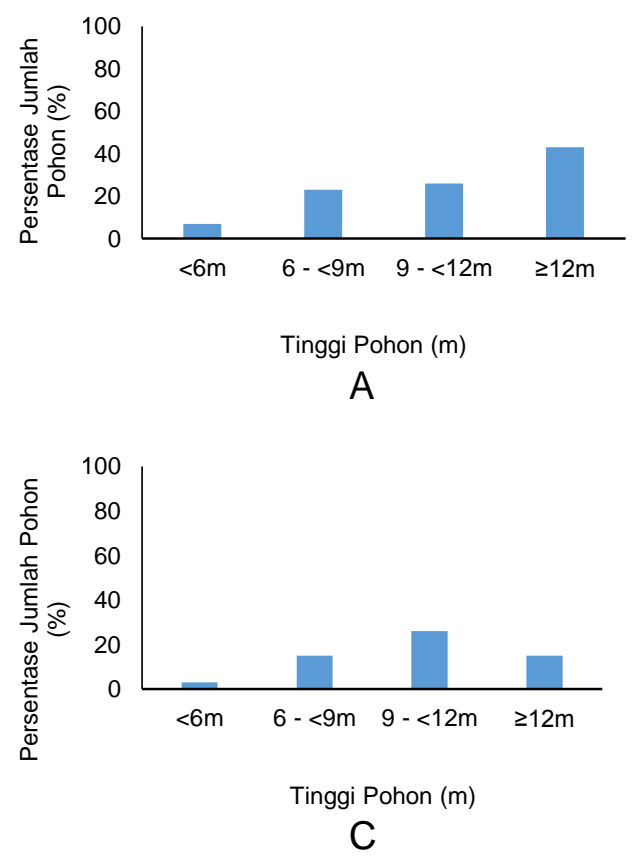

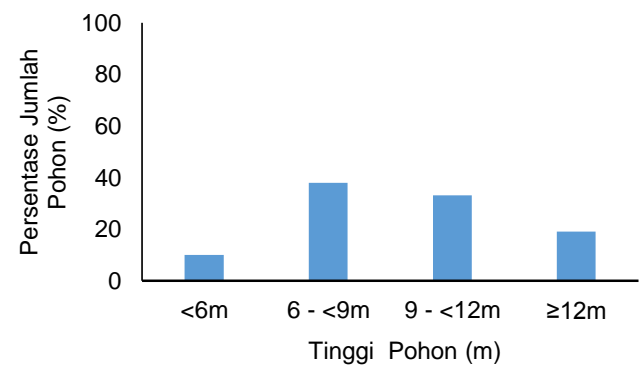

B

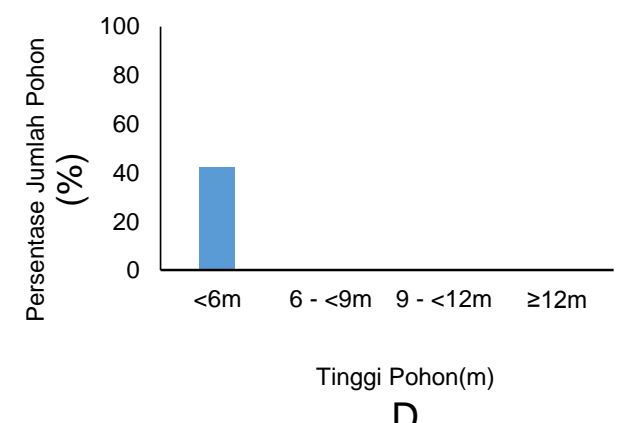

D

Gambar 6. Distribusi Nilai Rata-Rata Tinggi Pohon di Stasiun Penelitian (A: BW 1, B: BW 2, C: BW 3, D: BW 4). 
Perbedaan ketinggian didapatkan karena beberapa faktor yaitu, spesies, umur dan kondisi lingkungan. Stasiun BW 1 dan BW 2 didominansi oleh mangrove dengan spesies Rhizhopora apiculata didominansi ketinggian yang berbeda dikarenakan lokasi Stasiun BW 1 memiliki kondisi lingkungan yang lebih baik dengan kadar bahan organik total sebesar 46,19\% dibandingkan dengan Stasiun BW 2 dengan total bahan organik 35,04\%. Stasiun BW 3 didominansi oleh spesies Rhizophora mucronata dengan total bahan ogranik 31, 02\% dan Stasiun BW 4 didominansi oleh spesies Avicennia marina dengan total bahan organik 53,53\%. Stasiun BW 4 ditemukan paling besar bahan organiknya tetapi hanya ditemukan tinggi pohon pada kelas $<6 \mathrm{~m}$. Hal ini dikarenakan Stasiun BW 4 adalah kawasan mangrove hasil rehabilitasi yang belum terlalu lama sehingga memiliki umur jauh lebih muda dibandingkan mangrove di stasiun lain. Menurut Chapman (1976), hutan mangrove dewasa umumnya memiliki tinggi vegetasi berkiar $10-30 \mathrm{~m}$ bahkan lebih. Ketinggian pohon akan sangat mempengaruhi nilai kerapatan kanopi mangrove.

Hasil penelitian tutupan kanopi mangrove di seluruh stasiun penelitian ditunjukan pada Tabel 2 menunjukan bahwa dari 4 stasiun penelitian 3 stasiun memiliki tutupan kanopi dalam kategori padat dan 1 stasiun pada kategori sedang. Stasiun dengan kategori tutupan kanopi padat ditemukan di Stasiun BW 1, BW 2 dan BW 3, sedangkan untuk stasiun dengan kategori tutupan kanopi sedang ditemukan di Stasiun BW 4. Tabel 1 menjelaskan bahwa nilai tutupan kanopi mangrove paling tinggi ditemukan di Stasiun BW 1 sebesar 91,56 $\pm 2,63 \%$ dan paling kecil ditemukan pada Stasiun BW 4 sebesar 59, 62 \pm ,86 \%. Untuk Stasiun BW 2 dan BW 3 berturut turut adalah $84,08 \pm 13,43$ dan $89,02 \pm 2,80$. Nilai rata - rata tutupan kanopi pohon mangrove yang didapatkan adalah $81,07 \%$.

Persentase tutupan kanopi mangrove di lokasi penelitian Desa Betahwalang berdasarkan Tabel 2 rata - rata tutupan kanopi mangrove di seluruh stasiun penelitian adalah $81,07 \%$ dan berstatus padat. Persentase tutupan kanopi secara keseluruhan di lokasi peneltian memiliki nilai berkisar 59, 62 $\pm 5,86$ - 91,56 $\pm 2,63 \%$. Persentase tertinggi didapatkan di Stasiun BW 1 sebesar $91,56 \pm 2,63$ tergolong padat dan persentase terendah didapatkan di Stasiun BW 4 sebesar 59, $62 \pm 5,86 \%$ tergolong dalam kategori sedang. Stasiun dengan tutupan kanopi mangrove kategori padat mendominansi di lokasi penelitian. Stasiun BW 1 memiliki nilai persentase tutupan kanopi tertinggi dikarenakan mangrove didominansi oleh spesies Rhizophora apiculata sedangkan Stasiun BW 4 memiliki nilai persentase tutupan terendah dikarenakan mangrove didominansi oleh spesies Avicennia marina. hal ini dikarenakan spesies Rhizophora apiculata memiliki bentuk daun yang lebih besar dan umur mangrove yang lebih tua sehingga bentuk kanopi lebih sempurna dibandingkan spesies Avicennia marina yang ada di Stasiun BW 4 dengan umur mangrove yang lebih muda.

Hasil yang didapatkan lebih baik dibandingkan dengan penelitian pada kawasan TWP Gili Matra (Dharmawan \& Akbar, 2017) berkisar 49,02 \pm 21,19 \% - 70,49 $\pm 4,24 \%$ didominansi oleh spesies Avicennia marina. Perbedaan nilai persen cover yang didapatkan diakibatkan adanya perbedaan dominansi spesies mangrove yang menyusun lokasi tersebut. Sedangkan pada Hasil penelitian Anthoni et al. (2017) tutupan kanopi yang didominansi oleh spesies Rhizhopora mucronata memiliki tutupan sebesar 82,78\%. Menurut Tomilinson (1994) Ukuran daun Rhizophora sp. Memiliki ukuran lebih besar dibandingkan dengan Avicennia sp. dan pembentukan kanopi oleh spesies Rhizophora sp. adalah percabangan bertingkat yang pendek sehingga luas tutupan kanopinya menjadi sepit dan cenderung membentuk percabangan tidak normal. Menurut Pretzsch (2015) semakin besar luas tumpang daun maka akan semakin rapat tutupan kanopi, hal ini yang menyebabkan perbedaan spesies juga akan memiliki perbedaan pada luas tumpang daunya.

Tabel 2. Persentase nilai tutupan kanopi mangrove dan status kerapatan di stasiun penelitian.

\begin{tabular}{ccccc}
\hline No & Stasiun & $\begin{array}{c}\text { \%Tutupan } \\
( \pm \text { StdDev })\end{array}$ & Status & Rata - Rata \\
\hline 1 & BW 1 & $91,56 \pm 2,63$ & Padat & 81,07 \\
2 & BW 2 & $84,08 \pm 13,43$ & Padat & \\
3 & BW 3 & $89,02 \pm 2,80$ & Padat & \\
4 & BW 4 & $59,62 \pm 5,86$ & Sedang & \\
\hline
\end{tabular}


Desa Betahwalang berdasarkan hasil analisis data vegetasi, Kerapatan mangrove yang didapatkan adalah 1.066-3.066 ind/ha, hal ini berpengaruh juga terhadap tinggi rendahnya persen cover mangrove. Stasiun BW 1 yang memiliki nilai persen cover yang paling tinggi di seluruh lokasi peneltian di Desa Betahwalang juga memiliki nilai Kerapatan yang paling tinggi juga sebesar 3066 ind/ha sedangkan pada stasiun BW 4 yang memiliki nilai persen cover paling kecil di lokasi penelitian juga memiliki nilai Kerapatan paling rendah yaitu sebesar $1.066 \mathrm{ind} / \mathrm{ha}$. Ketinggian pohon juga berpengaruh terhadapat besar kecilnya persen cover mangrove. Semakin tinggi pohon maka semakin sempurna tutupan kanopinya. Hal ini dikarenakan persen cover di Stasiun BW 1, BW 2, dan 3 dengan distribusi tinggi yang beragam dari $6 \geq 12 \mathrm{~m}$ memiliki nilai persen cover mangrove lebih tinggi dibandingkan dengan distribusi tinggi yang seragam hanya $<6 \mathrm{~m}$ di Stasiun BW 4. Tinggi rendahnya persen cover mangrove akan berpengaruh terhadap kelangsungan hidup anakan dan semai mangrove hal ini dikarenakan menghalangi sinar matahari yang seharusnya didapatkan oleh anakan dan semai mangrove untuk proses fotosintesis. Menurut Sadono (2018) semakin rapat tajuk maka akan semakin sulit cahaya matahari menembus kanopi pohon sehingga kategori anakan dan semai kurang dalam mendapatkan kebutuhan sinar matahari.

\section{KESIMPULAN}

Persentase tutupan kanopi mangrove di Desa Betahwalang memiliki nilai kanopi mangrove paling tinggi di Stasiun BW 1 sebesar 91,56 $\pm 2,63 \%$ termasuk kedalam kategori padat dan terkecil di temukan di Stasiun BW 4 sebesar 59, 62 $\pm 5,86 \%$ termasuk kedalam kategori sedang. Sehingga Kondisi Ekosistem Mangrove di Desa Betahwalang tergolong baik oleh karena perlu di pertahankan dengan merawat dan melakukan rehabilitasi mangrove dengan spesies yang beragam sehingga akan menghasilkan ekosistem mangrove yang beragam.

\section{DAFTAR PUSTAKA}

Akbar, N., Marus, I., Haji, I., Abdullah, S., Umalekhoa, S., Ibrahim, F.S., Ahmad, M., Ibrahim, A., Kahar, A. \& Tahir, I., 2017. Struktur Komunitas Hutan Mangrove di Teluk Dodinga, Kabupaten Halmahera Barat Provinsi Maluku Utara. Jurnal Enggao, 2(1):78-89. DOI. 10.31186/ jenggano.2.1.78-89.

Anthoni, A., Schaduw, J. \& Sondak, C., 2017. Persentase tutupan dan struktur komunitas mangrove di sepanjang pesisir Taman Nasional Bunaken bagian utara. Jurnal Pesisir dan Laut Tropis, 5(3):13-21..DOI.10.35800/jplt.5.3.2017.16909.

Baksir, A., Mutmainnah, Akbar, N. \& Ismail, F. Penilaian Kondisi Menggunakan Metode Hemispherical Photography Pada Ekosistem Mangrove Di Pesisir Desa Minaluli, Kecamatan Mangoli Utara, Kabupaten Kepulauan Sula, Provinsi Maluku Utara. Jurnal Sumberdaya Akuatik Indopasifik, 2(2):69-80, DOI: 10.30862/jsai-fpik-unipa.2018.Vol.2.No.2.52

Bianchi, S., Crhistine., Sophie \& James. 2017. Rapid Assessment of Forest Canopy and Light Regime Using Smartphone Hemispherical Photography. Journal Ecology and Evolution, 7(2): 10556-1066. DOI: 10.1002/ece3.3567.

Chapman, V.J. 1976. Mangrove Vegetation. J. Cramer, Vaduz, Liechtensin, Germany.

Chianucci, F. \& Andrea, C. 2012. Digital Hemispherical Photography for Estimating Forest Canopy Properties: Current Controversies and Opportunities. I-Forest-Biogeosciences and Foresty, 5:290-295. DOI: 10.3832/ifor077-005.

Cintron, G. \& Noveli. 1984. Methode for Studying Mangrove Stucture in S.C. Snedaker and J.G. Snedaker (eds). The Mangrove Ecosystem Research Methods. Unesco, Paris.

Dharmawan, I.W.E \& Pramudji. 2017 Kajian Kondisi Kesehatan Ekosistem Mangrove di Kawasan Pesisir Kabupaten Lampung Selatan. COREMAP-CTI Pusat Penelitian Oseanografi, LIPI. Jakarta.

Dharmawan, I.W.E. \& Akbar, N. 2017. Status Terkini Kondisi Komunitas Mangrove di Taman Wisata Perairan Gili Matra, Lombok Utara, Nusa Tenggara Barat. Prosiding Seminar Nasional Kemaritiman dan Sumber Daya Pulau - Pulau Kecil., 1(1):38-43.

Edi H., Ali, D. \& Redjeki, S. 2018. Beberapa Aspek Biologis Rajungan (Portunus pelagicus) di Perairan Betah Walang. Jurnal Kelautan Tropis., 21(1):22-60. DOI: 10.14710/jkt.v21i1.2409. 
Fuady, I., Rudhi., P. \& Nirwani. 2013. Struktur Komunitas Mangrove Di Pulau Jemaja, Kabupaten Kepulauan Anambas, dan Pulau Liran, Kabupaten Maluku Barat Daya. Journal of Marine Research., 2(2):94-102. DOI:10.14710/jmr.v2i2.2470.

Keputusan Menteri Lingkungan Hidup Nomor 201 Tahun 2004 Tentang Kriteria Baku dan Penentuan Kerusakan Mangrove.

Kurniawan, C., Pribadi, R., \& Nirwani, N. 2014. Struktur dan Komposisi Vegetasi Mangrove di Tracking Mangrove Kemujan Kepulauan Karimun Jawa. Jurnal of Marine Research., 3(3):351358.

Marhamah, M. 2015. Pengukuran Tinggi Pohon. Departemen Konservasi Sumber Daya Hutan dan Ekowisata Fakultas Kehutanan Institut Pertanian Bogor.

Mauludin, R.Z., Azizah, R., Pribadi, R. \& Suryono. 2018. Komposisi dan Tutupan Kanopi Mangrove di Kawasan Ujung Piring Kabupaten Jepara. Buletin Oseanografi Marina, 7(1):29-36. DOI: 10.14710/buloma.v7i1.19039.

Pretzsch, H., Biber, P., UHL, E., Dahlhausen, J., Rötzer, T., Caldentey, J., Koike, T., Van Con, T., Chavanne, A., Seifert, T. \& Du Toit, B., 2015. Crown size and growing space requirement of common tree species in urban centres, parks, and forests. Urban forestry \& urban greening, 14(3):466-479. DOI: 10.1016/j.ufug.2015.04.006.

Sadono, R. 2018. Prediksi Lebar Tajuk Pohon Dominan pada Pertanaman Jati Asal Kebun Benih Klon di Kesatuan Pemangkuan Hutan Ngawi, Jawa Timur. Jurnal IImu Kehutanan, 12:127141. DOI: $10.22146 / j i k .40143$.

Susilo. 2017. Analisis Vegetasi Mangrove (Rhizophora) di Pesisir Pantai Pulau Menjangan Besar Karimunja. Biomedika, 10(2):58-68. DOI: 10.31001/biodemika.v10i2.276.

Tomlinson, P. B. 1994. The Botany of Mangroves. Cambridge University Press. New York. 